\title{
Moving Labor Heroes Center Stage: (Labor) Heroism and the Reconfiguration of Social Relations in the Yan'an Period
}

\author{
Nicola Spakowski* ${ }^{(1)}$ \\ Albert-Ludwigs-Universität Freiburg \\ ${ }^{\star}$ Corresponding author. Email: nicola.spakowski@sinologie.uni-freiburg.de
}

(Received 12 August 2019; revised 17 January 2020; accepted 17 January 2020)

\begin{abstract}
Labor heroes are an important phenomenon in the history of socialist China, but they have received only little attention in Western scholarship. This article investigates the labor heroes of the Yan'an period as the pivot in the Chinese Communist Party's (CCP) attempt at reconceptualizing society, establishing new social relations and creating a socialist subjectivity. It reveals the new symbolic order constructed in the official media, primarily Jiefang Ribao (Liberation Daily), and highlights the relation between labor heroes (as representatives of the "masses"), intellectuals, and Mao Zedong in the construction of new hierarchies. In particular, it shows how the CCP chose work as the fundament of socialist society and the core of a new concept of "collective heroism"; how the stage of the first labor hero assembly was used to orchestrate Mao Zedong as a charismatic leader; and how labor heroes and writers, through direct encounter, redefined their respective place in society.
\end{abstract}

Keywords: labor heroes; China; Yan'an; Mao Zedong; Mao cult

In his book-length report on Yan'an, published in 1945, foreign correspondent Gunther Stein ${ }^{1}$ opened the chapter on the peasantry with the remarkable sentence: "No person except Generalissimo Chiang Kai-shek himself has such fame in the Chungking areas as Wu Men-yu [= Wu Manyou], a plain peasant, has in the Yenan regions."2 Stein referred to the various social groups in Yan'an who spoke highly of $\mathrm{Wu}$, including Mao Zedong,

The author would like to thank Ulrich Bröckling, Dong Limin, Daniel Leese, Leng Jia, Zhao Ma and two anonymous reviewers who commented on earlier versions of this article. Research for this work was funded by the German Science Foundation (DFG).

${ }^{1}$ Stein was a member of a group of journalists who spent three months in Yan'an to get first-hand insights into the fabric of Yan'an as the center of “Red China." For the delegation, see Lu Yi 盧毅, “1944 nian Zhong wai jizhe tuan fangwen Yan’an fengbo” 1944 年中外記者團訪問延安風波, Guangdong shehui kexue 2015.1, 120-30.

${ }^{2}$ Gunther Stein, The Challenge of Red China (New York: Da Capo, 1975, first published 1945).

(C) Cambridge University Press 2020. This is an Open Access article, distributed under the terms of the Creative Commons Attribution licence (http://creativecommons.org/licenses/by/4.0/), which permits unrestricted re-use, distribution, and reproduction in any medium, provided the original work is properly cited. 
and concluded the first paragraph with the statement: "Wu Men-yu is the first of the Labor Heroes of whom so much is made in the Border Region." 3

This quotation is remarkable for two reasons. First, it reflects the extraordinary publicity of labor hero $\mathrm{Wu}$ Manyou 吳滿有 ${ }^{4}$ as an individual and the significance of labor heroes as a new social phenomenon in general. This publicity and significance is also reflected in Chinese sources of the time: Wu Manyou's life and merits were the subject of 111 articles in Jiefang Ribao 解放日報 (JFRB, Liberation Daily), ${ }^{5}$ the communist mouthpiece. ${ }^{6}$ Innumerable additional articles and products of various arts and genres covered the lives and merits of him and other labor heroes, male and female. Chinese contemporaries, too, regarded Wu Manyou as the "hero among heroes."7 The second reason the quotation is worthy of note is the reversal of established hierarchies in Stein's description of Yan'an society where a "plain peasant" has the fame of a paramount leader-while the obvious candidate for this role, Mao Zedong, is reduced

\footnotetext{
${ }^{3}$ Stein, The Challenge of Red China, 157.

${ }^{4}$ Wu Manyou (1893-1959), together with Zhao Zhankui 趙佔魁, were the first and most prominent labor heroes of the Yan'an period. The two were promoted as models for peasants and workers respectively. Fleeing famine, Wu Manyou had arrived in Yan'an in 1928. During land reform in 1935 he was distributed land which, due to his hard work, yielded increasing crops. The Party bestowed him with the title labor hero and, starting in April 1942, held him up as a model for peasants to learn from. The CCP leadership regarded him highly, and in 1946 Mao Zedong even sent his son Mao Anmin, who had just returned from the Soviet Union, to live with $\mathrm{Wu}$ and learn how to work the fields. Wu's case was contested, though. His economic success and in particular the fact that he employed workers made him a "new rich peasant" and caused a discussion about policy on this potentially exploitative new class. Furthermore, in $1948 \mathrm{Wu}$ was captured by GMD troops and later appeared at a press conference organized by the Nationalist government where he said he would follow Chiang Kai-shek. Scholars debate whether Wu was forced to do so or had defected to the GMD. Given the problematic status of Wu after his capture, the CCP erased him from public memory and later refused to rehabilitate him. See Li Rui 李銳, "Laodong yingxiong Wu Manyou zhende panbian toudi le ma? “勞動英雄吳滿有真的叛變投敵了嗎?, Yanhuang chunqiu 1995.4, 66-70 and Zhou Haiyan 周海燕, “Wu Manyou: Cong jiyi dao yiwang - "Jiefang ribao" shou ge "dianxing baodao" de xinwen shengchan yu shehui jiyi jiangou” 吳滿有: 從記憶到遺忘一《解放日報》首個“典型報道”的新聞生產 與社會記憶建構, Jiangsu shehui kexue 2012.3, 236-40.

${ }^{5}$ Jiefang Ribao was the CCP's party organ during the Yan'an period. It was founded in May 1941, reorganized in April 1942, and discontinued in March 1947. Authors were leading cadres and intellectuals under the guidance of the Party. Jiefang Ribao is said to have had a maximum print run of 7,600 copies, but through a number of organizational measures and activities such as newspaper reading groups, the audience it reached was much larger. In 1944, more than 10,000 people in the Shaan-Gan-Ning region participated in newspaper reading groups. For basic features and the history of the paper, see Patricia Stranahan, Moulding the Medium: Chinese Communist Party and the "Liberation Daily" (London: Routledge, 1990). For the numbers of circulation and channels of distribution, see Xu Chong 許沖, “Shilun Mao Zedong sixiang shehuihua de fangshi-yi 'Jiefang Ribao' wei kaocha duixiang” 試論毛澤 東思想社會化的方式一 以《解放日報》為考察對象, Mao Zedong sixiang yanjiu 2008.5, 17-21. Even though the reorganization in 1942 meant a stricter ideological control of contents and style, and even though the paper played a major role in the "rectification" of intellectuals, close reading reveals the existence of still some leeway for authors even after that date. This is particularly true for reportage texts on labor heroes and heroines; see Nicola Spakowski, "Yan'an's Labor Heroines and the Birth of the Women of New China," Nan Nü: Men Women and Gender in China 2020 (forthcoming).

${ }^{6}$ Cui Lili 崔莉莉, “Wu Manyou yundong’ yu changshi ‘Wu Manyou’ de dansheng” “吳滿有運動”與長 詩《吳滿有》的誕生, Yan'an daxue xuebao 2011.4, 48-53, here 50.

${ }^{7}$ Yuan Shengyong 袁盛勇, “Yan'an shiqi wenren xintai de xingcheng” 延安時期文人心態的形成, Wenyi zhengming 2010.11, 63-66, here, 64.
} 
to the role of an admirer of $\mathrm{Wu}^{8}{ }^{8}$ It is not too surprising that leftist Stein denied the existence of a true equivalent to the Generalissimo in egalitarian "Red China." On closer inspection, however, the emerging Mao cult is evident in Stein's very chapter on Wu Manyou and the peasants, ${ }^{9}$ and Stein can only poorly conceal the dilemma posed by leadership and leadership cults in a communist and "collectivist" context. Still, he seems to have sensed the exceptional nature of the relation between Mao and $\mathrm{Wu}$, and he is certainly right in recognizing $\mathrm{Wu}$ Manyou (and other labor heroes) as the pivot in the redefinition of social hierarchies and subjectivities in China's transition to socialism or-in the parlance of Chinese ideologues of the time-"New Democracy" (xin minzhuzhuyi 新民主主义). ${ }^{10}$

Labor heroes are an important phenomenon in the history of socialist China, but they have received little attention in Western scholarship. ${ }^{11}$ They first appeared in the Communists' Shaan Gan Ning border area in 1942 in the context of the Great Production Movement, a major production campaign launched in 1939 in order to raise productivity and overcome the material shortages caused by the Nationalist Party's (Guomindang 國民黨, GMD) blockade of the border region. Wu Manyou was indeed the first "labor hero" in Shaan Gan Ning, but many others followed.

A comprehensive account of labor heroes' role in Yan'an communism would have to acknowledge the multi-dimensionality of the phenomenon and in particular highlight labor heroes' contribution to the material transformation of the border region, as producers and as multipliers of new methods in agriculture and industry; their role as intermediaries or even quasi cadres in the implementation of Party policies at the grassroots; their role as representatives of the "masses" in narratives of individual fanshen 翻身 ${ }^{12}$ and collective revolution; their function as models of socialist man and new social relations under socialism; and their instrumentalization in processes of political legitimization. My emphasis here is on the latter two aspects. I offer an analysis of the social transformation of Yan'an that recognizes the central role of labor heroes in the Chinese Communist Party's (CCP) attempt at reconceptualizing society, establishing new social relations and creating a socialist subjectivity. In particular, I will reveal the new symbolic order constructed in the official media, primarily JFRB, and highlight the relation between labor heroes (as representatives of the "masses"), intellectuals,

\footnotetext{
${ }^{8}$ See Stein, The Challenge of Red China, 157: "Mao Tse-tung refers to him [= Wu Manyou] with respectful affection as one of the individuals who have contributed most to the great expansion of agricultural crops which made the Border Region safe against the Kuomintang's attempts to starve it out by blockade."

${ }^{9}$ Stein, The Challenge of Red China, 168 quotes peasants who sing an early version of "The East is Red," including the line that makes Mao the savior of the Chinese people.

10"New Democracy" is a sophisticated political and historical concept that denotes a transition period between "old" or "bourgeois" democracy and socialism proper and covers the years between the May Fourth Movement of 1919 and the official declaration of socialism in 1953. In the Yan'an period, the move towards a future socialist society was quite obvious, and labor heroes, in particular labor heroines, were important elements in visions of future socialist "New China." For the importance of New Democracy as a period of incipient socialism in the construction of labor heroes and particularly labor heroines, see Spakowski, "Yan'an's Labor Heroines." In the present article, I ignore the theoretical arguments on New Democracy and use the term "socialism" instead, thus highlighting contemporaries' awareness of Yan'an as a society of incipient socialism.

${ }^{11}$ For an introduction to the phenomenon in Western languages, see Mary Sheridan, "The Emulation of Heroes," China Quarterly 33 (1968), 47-72; Patricia Stranahan, "Labor Heroines of Yan'an,” Modern China 9.2 (1983), 228-52. For an excellent overview in Chinese, see Sun Yun 孫雲, “Zhonggong yingmo biaozhang zhidu de zhaoshi yu yanbian” 中共英模表彰制度的肇始及演變, Dang de wenxian 2012.3, 71-82.

${ }^{12}$ Literally "turn the body." Fanshen meant the individual act of joining the revolution.
} 
and Mao Zedong in the construction of new hierarchies. This symbolic order functioned as a "subpolitical order of legitimacy"13 that amended formal rules and official ideology, partly filling voids and partly modifying or even contradicting newly established structures and proclaimed ideals. Even though JFRB, as a propaganda medium, gives us only part of the story on labor heroes, and only selected insights into the problems of the labor hero campaign, it is an excellent source for understanding what the Party wished people to believe.

The argument is based on theories of power and subjectivity that stress recognition as a core process in the formation of power and subjectivities and highlight relationality and reciprocity in acts of recognition. ${ }^{14}$ Rather than perceiving power as a zero-sum game or identifying linear cause-effect relationships in social processes, they stress interactive practices in the constitution of social relations. And rather than dividing the social into clear-cut spheres of rulers and ruled, they highlight configurations of relations that include more than just two actors or groups of actors. ${ }^{15}$ In addition, my argument is informed by concepts of heroism and heroization that stress the ambiguity of exceptionality and exemplarity of heroic figures and allow for identifying particular roles in heroizations as acts of social distinction. ${ }^{16}$ When Yan'an is viewed through the lens of such a configurational understanding of power, the CCP remains the power center that instigates social processes that result in new hierarchical relations. Still, these relations rest on imagined and real acts of mutual recognition as they are reflected in the following three thematic complexes-which also form the three parts of the article.

The first thematic complex is terminology, and the dilemma of heroism in a communist context. Communist theory stresses the collective in the historical process and envisages a society of equals; heroism as a form of distinction, if not glorification, on the other hand, highlights the individual and introduces hierarchies into visions of society. The new concept of "collective heroism" could not completely cover up this dilemma, the continuing belief in heroes, and the struggle among communist leaders over the true fields of heroic action. The specific concept of "labor heroes" (laodong yingxiong 勞動英雄), on the other hand, could be embedded in a materialist view of history and the definition of socialist society as a society of production. Theorists made work the foundation of society, the core source of recognition and the mechanism that shaped social relations-with the status of and relation between workers/peasants

\footnotetext{
${ }^{13}$ Klaus Kraemer, “Charismatischer Habitus: Zur sozialen Konstruktion symbolischer Macht,” Berliner Journal für Soziologie 2 (2002), 173-87, here, 181.

${ }^{14}$ See, in particular, Wolfgang Sofsky and Rainer Paris, Figurationen sozialer Macht. Autorität, Stellvertretung, Koalition (Frankfurt: Suhrkamp, 1994); Norbert Ricken, “Anerkennung als Adressierung: Über die Bedeutung von Anerkennung für Subjektivationsprozesse," in Selbst-Bildungen: Soziale und kulturelle Praktiken der Subjektivierung, edited by Thomas Alkemeyer, Gunilla Budde, and Dagmar Freist (Bielefeld: transcript, 2013), 69-99; Norbert Ricken, "Zur Logik der Subjektivierung. Überlegungen an den Rändern eines Konzepts," in Techniken der Subjektivierung, edited by Andreas Gelhard, Thomas Alkemeyer, and Norbert Ricken (München: Wilhelm Fink: 2013), 29-47; Kraemer, "Charismatischer Habitus."

${ }^{15}$ For relational approaches in the analysis of labor heroes, Mao and intellectuals-albeit with different frameworks of discussion and emphases—-see also Yuan, “Yan'an shiqi wenren xintai” and Wu Jing 吳靜, “Shenfen, juese yu tuxiang-1940 niandai Shaan Gan Ning bianqu 'laodong yingxiong' xingxiang de suzao luoji”身份、角色與圖像—1940 年代陝甘寧邊區“勞動英雄”形象的塑造邏輯, Wenyi lilun yu piping 2018.3, 146-57.

${ }^{16}$ Spakowski, "Yan'an's Labor Heroines.”
} 
and intellectuals at the core of this fundamental transformation. Indeed, based on this fundamental understanding of society, labor heroes could become an enduring phenomenon in the history of Chinese socialism. As "labor models" (laodong mofan 勞動模范) - a term that denotes exemplarity and standardization rather than exceptionality-they represented socialist man. At the same time, these new theoretical concepts also backed immediate pragmatic considerations of spurring productivity in the context of the Production Movement. ${ }^{17}$

The second complex is the political legitimacy and the orchestration of Mao as a charismatic leader. ${ }^{18}$ Scholarship on the Yan'an period has uncovered traces of an emerging Mao cult in the early 1940s. ${ }^{19}$ Indeed, the misplacement of Mao in Gunther Stein's account as a mere admirer of Wu Manyou has no equivalent in the Chinese primary sources. These sources construct Mao as a charismatic leader, based on a process of reciprocal recognition: Mao recognized the labor heroes (who represented the masses) as the new providers of legitimacy; the labor heroes recognized Mao as their true leader and even "savior." It is true, charisma was only one source of legitimacy for the new order, standing alongside new narratives of revolution or fanshen, codified political principles, and the improvement of people's livelihood through increased productivity. ${ }^{20}$ Still, the elevation of Mao was important in a national

\footnotetext{
${ }^{17}$ For the contradictions between immediate, pragmatic and long-term, idealist concerns in the labor hero discourse, see Spakowski, "Yan'an's Labor Heroines."

${ }^{18}$ This study is based on scholarship that understands charisma as a "product of cognition, interaction and attribution." See Michael N. Ebertz, "Charisma und 'das Heroische'," in helden.heroes.héros 4.2 (2016), 6, https://freidok.uni-freiburg.de/fedora/objects/freidok:12366/datastreams/FILE1/content, as the result of a relation rather than the substance of the charismatic leader. Charisma is an attribution of exceptionality and thus dependent on the recognition of those who follow the charismatic leader; see Christoph Schneider, "Charisma: Sinnproduktion durch Reflexionsanästhesie," in Das Charisma: Funktionen und symbolische Repräsentationen, edited by Pavlína Rychterová, Stefan Seit and Raphaela Veit (Berlin: Akademie Verlag, 2008), 129-53, here, 139. Scholars who stress relationality also highlight the emotional bonds of charisma created through "performative-symbolic communication" (Schneider, "Charisma," 142). See also Valentin Rauer, "Magie der Performanz: Theoretische Anschlüsse an das Charisma-Konzept," in Das Charisma: Funktionen und symbolische Repräsentationen, 155-71. Charismatic leadership is bound to situations of hardship and crisis which necessitate a savior, see Ebertz, "Charisma und 'das Heroische'," 10-11. Charisma, in this view, is "not a particular form of legitimate political rule," "but a dimension of any form of symbolically mediated power" (Kraemer, "Charismatischer Habitus," 184).

${ }^{19}$ Raymond F. Wylie, The Emergence of Maoism: Mao Tse-tung, Ch'en Po-ta, and the Search for Chinese Theory, 1935-1945 (Stanford: Stanford University Press, 1980); Daniel Leese, Mao Cult: Rhetoric and Ritual in China's Cultural Revolution (Cambridge: Cambridge University Press, 2011), 4-12. Leadership cults are usually steered by a central state and backed by modern media and state resources; see Jan Plamper, The Stalin Cult: A Study in the Alchemy of Power (New Haven: Yale University Press, 2012). Ursprung sees leadership cults in socialist societies as a form of "orchestrated charisma"; see Daniel Ursprung, "Inszeniertes Charisma: Personenkult im Sozialismus," in Charisma und Herrschaft: Führung und Verführung in der Politik, edited by Berit Bliesemann de Guevara and Tatjana Reiber (Frankfurt: Campus, 2011), 151-76. For an excellent introduction to leadership cults in communist contexts, see Daniel Leese, "The Cult of Personality and Symbolic Politics," in The Oxford Handbook of the History of Communism, edited by Stephen A. Smith (Oxford: Oxford University Press, 2014), 339-54. For Chinese discussions of the emerging leadership cult during the Yan'an period, see, for instance, Yuan, “Yan'an shiqi wenren xintai”; Li Jihua 李繼華, “Dui Mao Zedong geren chongbai de zisheng” 對毛澤東 個人崇拜的滋生, Yanhuang chunqiu 2010.3, 40-45.

${ }^{20}$ For the various sources of legitimacy in specific periods of post-1949 China, see Frederick C. Teiwes, Leadership, Legitimacy, and Conflict in China: From a Charismatic Mao to the Politics of Succession
} 
and global context of rival leadership cults, ${ }^{21}$ in the face of a symbolic void at the top of a Party organization marked by collective leadership, ${ }^{22}$ and perhaps also as a form of personalized authority which, in the eyes of the Party, must have fitted a rural mindset. ${ }^{23}$ While this particular construction of charismatic leadership marginalized intellectuals as the traditional providers of legitimacy, it was through their texts that the masses were constructed as followers and admirers of Mao. Similar to leadership cults elsewhere, the charismatic relation between Mao and the labor heroes was a matter of performativity. ${ }^{24}$ It was on the stage of the first labor hero assembly in late 1943 and its quite distinctive orchestration of actors and symbols that the efforts at constructing Mao as charismatic leader were most obvious.

The third complex is the formation of a socialist subjectivity through the encounter of labor heroes and writers. As is well known, the Rectification Movement and the "Yan'an Forum on Literature and Art" made Yan'an a place of streamlining thought and subordinating intellectuals to new Maoist dogmas. ${ }^{25}$ However, a dichotomic view of a repressive state vs. autonomous intellectuals does not do justice to the complex processes of redefining status and creating subjectivities in the transition to socialism. Rather, new subjectivities were formed in the relation between Mao (as the source of new cultural policies), intellectuals (as the co-producers of a new symbolic order), and labor heroes (as imagined catalysts of intellectual self-reform, preferred objects of the new cultural policies, and even subjects of cultural production). This relational restructuring of the social fabric was more than just an appreciation of labor heroes at the expense of intellectuals. Instead, it was through the direct encounter between labor heroes and intellectuals that the former gained a status as subjects of socialism in the first place, while the latter "reformed" themselves and secured a legitimate place in socialist society.

\section{Terminology and the Theoretical Dilemma of Heroism in a Communist Context}

Awarding Wu Manyou and other peasants and workers the title of "hero" introduced a term into communist ideology that was alien to the theories of historical materialism and implied an exceptionalism which contradicted the idea of a society of equals. Indeed, before the labor hero movement was in full swing, "heroism" was a taboo term, ${ }^{26}$ and even at the time of the peak of the movement only a few texts tackled

(London: Macmillan, 1984). For Wu Manyou as an object in legitimizing CCP rule, see Zhou Haiyan, "Wu Manyou."

${ }^{21}$ For the construction of the Mao cult as a response to the cult of Chiang Kai-shek, see Leese, Mao Cult, 4-12; Wylie, The Emergence of Maoism, 195-96. For leadership cults as a global and also relational phenomenon at the time, see Plamper, The Stalin Cult, 25.

${ }^{22}$ See Ursprung, "Inszeniertes Charisma" on leadership cults in socialist societies.

${ }^{23}$ Leese, Mao Cult, 3.

${ }^{24}$ For the performative side of charisma, see Rauer, "Magie der Performanz" and Schneider, "Charisma."

${ }^{25}$ David E. Apter and Tony Saich, Revolutionary Discourse in Mao's Republic (Cambridge, MA: Harvard University Press, 1994); Dai Qing and David E. Apter, eds, Wang Shiwei and "Wild Lilies": Rectification and Purges in the Chinese Communist Party, 1942-1944 (Armonk, NY: Sharpe, 1994); Gao Hua, How the Red Sun Rose: The Origins and Development of the Yan'an Rectification Movement (Hong Kong: The Chinese University Press, 2018); Eddy U, Creating the Intellectual: Chinese Communism and the Rise of a Classification (Oakland: University of California Press, 2019).

${ }^{26}$ Dai Li 戴莉, “Xin yingxiong chuanqi de fashengxue kaocha-yi 'Jiefang ribao-wenyi' di si ban wei zhongxin” 新英雄傳奇的發生學考察— 以 《解放日報—文藝》第四版為中心, Yan'an daxue xuebao 2005.12, 5-9, here, 7-8. 
the problem of heroism in a communist context. ${ }^{27}$ This is even more true for other terms of the semantic field such as “leader" (lingxiu 領袖) or “model” (mofan 模范). Obviously, the problems inherant in the contaminated term were hard to solve. In addition, heroism's relation to questions of power invited disputes over the true fields of heroic action: politics, the battlefield, production, or intellectual work.

The major solution for Yan'an ideologues was to base heroism on Marxist philosophy and qualify it as "new" and "collective" - as opposed to an "old" heroism that centered on the individual. ${ }^{28}$ This was the main argument of "On New Heroism", an essay written by Wang Ziye 王子野" and published in JFRB on 19 July 1942: “The difference between new and old heroism is in essence the opposition between individualism and collectivism." ${ }^{30}$ Wang elaborated on the two concepts and how they are expressed in the hero's relation to the masses: they are either disregarded or even sacrificed in order to enhance the hero's own status, or he becomes a part of them. He supported his view by quoting Mao: "The masses are the real heroes, and we are always naive and ridiculous." ${ }^{1}$ While Wang's argument is not surprising, the text bears allusions that indicate how contested the issue was. First of all, the term "new heroism" had come up earlier, in the writings of left-wing writer Xiao Jun 萧军 and his problematic self-proclamation as a "new hero." 32 Second, Wang Ziye not only defined the lines between good and bad heroism, he also pitted military heroism against the heroism promulgated in the labor hero movement. In the paragraphs following the basic definition, Wang mentions Wu Manyou and Stakhanov as being filled with the "spirit of collectivism," but he also criticizes competitions where they become a “doctrine" (zhuyi 主義) and serve the effort of individuals to raise their position in a rank order. Wang compares the revolution to a battlefield (zhanchang 戰場) - as opposed to a "race course" (paodao 跑道) - and makes self-sacrifice for the cause of the revolution the final criterion of

\footnotetext{
${ }^{27}$ For a much richer discussion of the problem of the role of the individual in history in Western and Russian Marxism, see Jan Plamper, "Introduction: Modern Personality Cults," in Personality Cults in Stalinism-Personenkulte im Stalinismus, edited by Klaus Heller and Jan Plamper (Göttingen: V \& R unipress, 2004), 13-42.

${ }^{28}$ For an earlier example, see Liu Shaoqi, How to Be a Good Communist (Lun gongchandang yuan de xiuyang 論共產黨員的修養), July 1939, Part VII (“Examples of Wrong Ideology in the Party”), quoted from Liu Shaoqi Reference Archive, www.marxists.org/reference/archive/liu-shaoqi/1939/how-to-be/ index.htm, accessed 8 March 2019. In the context of the Rectification Movement, intellectuals were commonly accused of individual heroism; see Wu Min 吳敏, “Shilun 40 niandai Yan'an wentan de 'xiao zichanjieji huayu” 試論 40 年代延安文壇的“小資產階級”話語, Zhongguo xiandai wenxue yanjiu congkan 2004.2, 38-66, here, 43. Georgii Plekhanov's “On the Role of the Individual in History,” a text used to justify personality cults in communist contexts (Leese, The Cult of Personality and Symbolic Politics, 343) was not translated into Chinese before 1948.

${ }^{29}$ Wang Ziye had various leading positions in Party offices related to compilation and translation.

${ }^{30}$ Wang Ziye 王子野, “Tan xin yingxiongzhuyi” 談新英雄主義, Jiefang Ribao, 19 July 1942. See also Kong Jue 孔厥, “Xin de yingxiong” 新的英雄, Jiefang Ribao, 27 November 1943. The text mainly refers to examples among the labor heroes celebrated during the first labor hero assembly of November/ December 1943.

${ }^{31}$ The sentence is from Mao Zedong, “Nongcun diaocha' de xuyan he ba” 《農村調查》的序言和跋, March/April 1941, in Mao Zedong xuanji 毛泽东选集 (Beijing: Renmin, 1967), 747-52, here, 748.

${ }^{32}$ Xiao Jun 蕭軍, “Ye suan shi bi” 也算試筆, Jiefang Ribao, 1 January 1942. See also the account of eyewitness Li Xin on Xiao Jun's and other writers' relations to Mao around the time of the Yan'an Forum (Li Xin 黎辛, “Yan'an wenyi zuotanhui xiangguan de ren yu shi” 延安文㙯座談會相關的人與事, Xin wenxue shiliao 2012.3, 4-20). Li is referring to $\mathrm{Hu}$ Qiaomu who claimed that the Forum was about two persons, Xiao Jun and Ding Ling; see Li, “Yan’an wenyi zuotanhui,” 10.
} 
“new heroism.” The examples he provides are military heroes, namely Zuo Quan 左權, an Eighth Route Army general who was killed in China's war with Japan in 1942, and those people who had protected Sevastopol in the Soviet Union's war with Germany. Two years later, Zhu De, commander-in-chief of the Eighth Route Army, in a similar vein defended heroism where it was "new," "revolutionary," or a "heroism of the masses," and where it displayed a "collectivist spirit." But he bemoaned that the heroism of the communist armies did not receive sufficient recognition and spoke of the need for a systematic approach to what he called the "movement of new heroism" which was to be unfolded in all fields of communist activities. ${ }^{33}$ Indeed, in the second half of 1944 a decline of JFRB articles on labor heroes and an increase in articles on military heroes can be observed. ${ }^{34}$

A more substantial point of departure for theorizing heroism in a communist context was the new concept of work explained in a JFRB editorial of 8 April 1943. In "Establishing a New Concept of Work"35 the phenomenon of labor heroes was noted right at the beginning of the text, and paragraphs on raising productivity show its close relation to the Production Movement. This text stated the novelty of the phenomenon of labor heroes in Chinese history-as compared to the military and political heroes of the past-and emphasized the "work front" as the main field of heroic action and work as the source of a socialist subjectivity:

From the past to the present, there were only heroes in war or on the political stage; but now workers can become heroes. This is not a coincidence because Chinese history has already assumed new features. The regime of the border region is the regime of New Democracy which is totally new to China. This regime respects the working masses; in particular, it respects the active and progressive elements on the work front, and acknowledges them as true heroes. These labor heroes are persons of a new kind. ${ }^{36}$ They are liberated persons, they know the meaning of their own work and know why they work. ${ }^{37}$

Differing from the former text, this one explicitly took up the problem of intellectuals, thus building a bridge to the Rectification Movement. "Among some intellectuals, there still exist remnants of [the phenomenon] of looking down on work." 38 The text then quoted from another JFRB editorial on women's work which had criticized that some women cadres "are floating in the upper spheres, are idle and have nothing to do, and see this not as shameful but, to the contrary, as glorious" ${ }^{39}$ and claimed that

\footnotetext{
${ }^{33}$ Zhu De 朱德, “Balujun Xinsijun de yingxiongzhuyi” 八路軍新四軍的英雄主義, Jiefang Ribao, 7 July 1944.

${ }^{34}$ Tian Songlin 田鬆林, “Mofan wenhua yu Yan’an wenxue zhong de yingxiong xushi” 模范文化與延安 文學中的英雄敘事, Fujian shifan daxue xuebao 2018.2, 68-77, here 76 .

35“Jianli xin de laodong guannian” 建立新的勞動觀念, Jiefang Ribao, 8 April 1943.

${ }^{36}$ See also Kong, "Xin de yingxiong" which called labor heroes "new persons of new China." Interestingly, the notion of a "new person" or "new woman" is much more common in texts on female labor heroes, see Spakowski, "Yan'an's Labor Heroines.”

37"Jianli xin de laodong guannian."

38“Jianli xin de laodong guannian."

39“"Zhongguo gongchandang zhongyang weiyuanhui guanyu ge kang Ri genjudi muqian funü gongzuo fangzhen de jueding” 中國共產黨中央委員會關於個抗日根據地目前婦女工作方針的決定，Jiefang Ribao, 26 February 1943. Intellectuals were also accused of "individual heroism"; see U, Creating the Intellectual, 57.
} 
this phenomenon could be observed among intellectuals in general. Intellectuals were to be denied a status if they did not contribute to production:

Here, in the border region right now, “learned people” (dushu ren 讀書人) who are floating in the upper spheres, are idle and are divorced from reality should not have status; they are disgraceful. But people who participate in work and contribute to the development of the work of economic production should receive a lot of honor; they should receive as much honor as those people who are fighting the enemy bravely at the front. ${ }^{40}$

The clearest statement on the relationality between intellectuals and labor heroes and the reversal of status between the two groups was philosopher and ideologue Ai Siqi's 艾思奇 “Work is Rectification,” published in JFRB on 19 February 1944. ${ }^{41}$ This text also explicated the link between the Rectification Movement, the Production Movement, and the labor hero movement. ${ }^{42} \mathrm{Ai}$ called for intellectuals to participate in production and related it to the new concept of work embodied by the border region's labor heroes. By claiming that the future no longer lay with the youth but with the workers, Ai made production the core of the future society. He called workers and labor heroes the “true masters" and the “new zhuangyuan" 新狀元 ${ }^{43}$ of the new society, thus reversing the traditional hierarchy between intellectuals and workers: "If you are an expert who has read ten thousand books but do not learn from these people you will definitely fall behind." Ai also referred to the labor hero assembly and mentioned two concrete intellectuals-turned-labor heroes, as well as the poems by labor hero Sun Wanfu 孫萬福, ${ }^{44}$ as reflections of the joy labor heroes drew from work. In the final paragraph, he once more urged intellectuals to learn from the labor heroes and reform themselves in the light of the new concept of work: "To learn this new concept of work from the labor heroes, to learn how to become a worker of New

\footnotetext{
40"Jianli xin de laodong guannian." This paragraph also mirrors the strong moral dimension of the new concept of work. This dimension is particularly obvious where labor heroes were contrasted with "idlers" (erliuzi 二流子)-yet another target group in the mobilization for production and also a term used to reproach intellectuals outside production. See also Gao Gang who pointed out that villagers called women cadres “idlers” (Gao Gang 高崗, “Cong shengchan zhanxian shang kaizhan funü yundong” 從生產戰線上開展婦女運動, Jiefang Ribao, 10 March 1944), and Zhou Haiyan on the campaign against erliuzi (Zhou Haiyan 周海燕, “Xiangcun gaizao zhong de youmin guixun yu shehui zhili celüe kaocha-yi 'gaizao erliuzi’ yundong wei li” 鄉村改造中的游民規訓與社會治理策略考察—以 ”改造二流子»運動 為例, Jianghai xuekan 2012.5, 124-29.

${ }^{41}$ Ai Siqi 艾思奇, “Laodong jiu shi zhengfeng” 勞動就是整風, Jiefang Ribao, 19 February 1944.

${ }^{42}$ In his report to the Seventh Party Congress, April 1945, Mao, too, made them an integrated whole. He complained about Wang Shiwei and others and claimed: "The cultural workers did not want to labor among the workers and peasants. After the cheng-feng and production campaigns, the situation changed. Now Wu Man-yü and Chao Chang-k'uei are the heroes of the workers, peasants, and soldiers," see "Mao Tse-tung's Oral Report to the Seventh Party Congress: Summary Notes (24 April 1945)," Chinese Law and Government 1977.78, 3-27, here, 22.

${ }^{43} \mathrm{~A}$ zhuangyuan is a person who has received the highest scores on the highest level of the imperial examination system. The term xin zhuangyuan had been brought up in earlier speeches and texts, see "Gao Gang tongzhi zai bianqu laodong yingxiong daibiao dahui yu shengchan zhanlan hui kaimu dianli shang de jianghua” 高崗同志在邊區勞動英雄代表大會與生產展覽會開幕典禮上的講話, Jiefang Ribao, 27 November 1943 and “Yanshu fenqu laodong yingxiong xiang Mao Zhuxi xianci” 延屬分區勞 動英雄向毛主席獻詞, Jiefang Ribao, 2 December 1943.

${ }^{44}$ For the assembly and Sun Wanfu, see below.
} 
Democracy, is very important. It is very important in the process of intellectuals' own self-transformation." 45

"Establishing a New Concept of Work" and "Work is Rectification" clearly reached beyond the justification of heroism in a communist context. The two texts made socialist society a society of workers, and work the true field of regulating social relations and forming a socialist subjectivity. Based on the definition of work as the foundation of society, the CCP could claim legitimacy through the special relation between labor heroes and Mao Zedong (see Part 2 below) and urge intellectuals to reform themselves in the face of labor heroes (see Part 3 below).

If "heroism" was such a problematic term, why wasn't it dropped altogether? The direct relation of Yan'an's labor heroes to the system of labor heroes in the Soviet Union in both theory and practice probably made it a somewhat natural term for Chinese communists. ${ }^{46}$ Much less problematic was the term "labor model" which was used alongside the term "labor hero." Interestingly, the alternative term was neither defined nor theorized, and one can only speculate that it fitted the phenomenon so well that nobody felt the need to do so. The term "labor model" moved the phenomenon from notions of exceptionality to notions of exemplarity and standardization. A model is close to everyday life and invites emulation. Indeed, models generate new models. It is estimated that in the Shaan Gan Ning border region alone, 12,000 persons had been awarded the title of "labor hero" by January $1945 .{ }^{47}$ In addition, "model" could not only refer to persons but also to entire units or other forms of social organizations, such as a "model village." And it was also common outside communist circles. ${ }^{48}$ Propagating models as concrete examples of certain policies can be seen as part of an experimental approach in communist policy-making. ${ }^{49}$ Lack of definition was also true for the term "leader," 50 not to mention the elevated leader who was exceptional exactly because he hovered above any definable status. ${ }^{51}$ As we will see in the next section, this conceptual void was filled by a practice of glorifying Mao as the paramount "leader."

\section{Political Legitimacy and the Orchestration of Mao as a Charismatic Leader}

The propagation of labor heroes started with reports on Wu Manyou in April 1942, gained momentum with the full-scale $\mathrm{Wu}$ Manyou campaign announced in January

\footnotetext{
${ }^{45}$ Ai Siqi, "Laodong jiu shi zhengfeng."

${ }^{46}$ For the Stakhanovite movement as an inspiration for the CCP, see Sun, "Zhonggong yingmo biaozhang."

${ }^{47}$ Stranahan, Labor Heroines of Yan'an, 230.

${ }^{48}$ To trace the origins of the term and its use outside communist circles is beyond the scope of this article. As for the question of the sources of honoring labor heroes, some authors stress continuities to the traditional practice of conferring honors on the virtuous; see, for instance, Sun, "Zhonggong yingmo biaozhang" and Boerge Bakken, The Exemplary Society: Human Improvement, Social Control, and the Dangers of Modernity in China (Oxford: Oxford University Press, 2000).

${ }^{49}$ Sebastian Heilmann, "From Local Experiments to National Policy: The Origins of China's Distinctive Policy Process," The China Journal 59 (2008), 1-30.

${ }^{50}$ For an exception, see Liu Shaoqi, How to be a Good Communist. In Part VII ("Examples of Wrong Ideology in the Party”) Liu uses terms such as “great men” (偉大人物), “heroes” (英雄) and “leaders of great prestige” (有威信的群眾領袖), or “genuine leaders and heroes” (真正的領袖和英雄) in his denunciation of "individualistic heroism." Liu claims: "Yes, we need countless communist heroes and many mass leaders of great prestige in our Party and in the communist movement," but he also stresses that they have to bow to the will of the Party.

${ }^{51}$ Schneider, "Charisma," 141.
} 
1943, reached its peak at the time of the first labor hero assembly for the Shaan Gan Ning region in late 1943, and abated from about spring 1944. By the time of the second labor hero assembly at the turn of the year 1944/45, labor heroes were no longer central in the pages of JFRB. ${ }^{52}$

JFRB reports on labor heroes either centered on the labor hero campaign and its contribution to increasing production or on individual labor heroes. Both types of texts were important elements in legitimizing the Party's policies. The former demonstrated the success of the campaign for the development of the border region. The latter exemplified how labor heroes, as representatives of the masses, benefitted from the new regime and its policies. Their individual success stories of fanshen plus hard work were woven into a narrative of revolution and marked by a stark contrast between misery in the old and decent living conditions in the new society. ${ }^{53}$ JFRB was of course not the only medium used to spread the deeds and virtues of labor heroes. Rather, the campaign was multifaceted and employed a wide range of media, genres, and symbols to reach different social groups in different corners of the border region. ${ }^{54}$

The most outstanding and multifarious event among all these activities was the first labor hero assembly of November/December 1943 where 180 labor heroes (who represented around five hundred labor heroes of the entire border region) convened for twenty days to exchange their experience and receive recognition by the political leadership. ${ }^{55}$ JFRB reported extensively on the conference, from its solemn opening on 26 November to the final ceremony on 16 December. During these twenty days, the assembly or related topics were present in every single issue of the paper, on most days with a number of articles, many of them on the front page. On some days the entire front page was dedicated to the topic.

The immediate reason for the surge in propagating labor heroes in late 1943 was the Party's effort at further raising agricultural productivity by introducing collective methods. On 29 November, Mao Zedong took the stage of the labor hero assembly to deliver his speech “Get Organized” (Zuzhi qilai 組織起來), in which he called for everybody not only to participate in production but also to join collective forms, in particular the (low-threshold) "teams of labor exchange" (biangong dui 變工隊), a form of mutual help, and various forms of cooperatives. The take-home message for the labor heroes was to get their villages mobilized and organized and to strive for transforming them into “model villages" (mofan cun 模范村, mofan xiang 模范鄉). ${ }^{56}$ Indeed, most

\footnotetext{
${ }^{52}$ See JFRB of the respective years. The first report on Wu Manyou appeared on 30 April 1942, the announcement of the campaign on 11 January 1943. Primary sources on the movement give no clear reason why it ebbed away after 1944. One reason must have been the slight turn towards the collective rather than the individual in mobilizing "heroic" action which was obvious in Mao's speech "Get organized" (see below) and in the call for constructing “model villages” (模范鄉村), see Mai Zhengfeng 麥正鋒, “Wu Manyou yundong yu xin minzhuzhuyi shiqi Zhonggong nongcun jingji zhengce” 吳滿有運動與新民主 主義時期中共農村經濟政策, Dang shi yanjiu yu jiaoxue 2014.2, 31-39, here, 35. The Party's more resolute treatment of labor heroes since about fall 1944 (see below) might have played a role, too.

${ }^{53}$ For these general trends, see Spakowski, "Yan'an's Labor Heroines."

${ }^{54}$ Chen Zhonghong 陳忠紅 and Song Shan 宋珊, “Wenyi xiaxiang: Zuo wei yi zhong wenyi zhidu de queli” 文藝下鄉：作為一種文藝制度的確立, Tianshui shifan xueyuan xuebao 2018.2, 66-70; Zhang Weibo 張衛波, “Kang Ri genjudi ‘wenhua xiaxiang' yundong de dongyuan, xingqi ji yingxiang” 抗日根 據地“文化下鄉”運動的動員、興起及影響, Beijing dangshi 2015.4, 4-9.

${ }^{55}$ For the numbers, see “Liang da shenghui longzhong juxing bimu dianli” 兩大盛會隆重舉行閉幕典 禮, Jiefang Ribao, 19 December 1943.

${ }^{56}$ Mao Zedong, “Zuzhi qilai” 組織起來, Jiefang Ribao, 2 December 1943.
} 
articles quoted below referred to the slogan "get organized," thus showing the importance of this concrete policy. This push for economic rationality was further supported by a three month long exhibition of agricultural products which not only testified to the impressive results of the Production Movement but also offered a suitable context for listening to labor heroes' experiences in production. JFRB articles on the exhibition, on particular fields and methods of agricultural production, on labor heroes' individual experiences in production, and on their production plans for 1944 all contributed to spreading relevant knowledge and demonstrating the rationality in the Party's economic approach as well as the rationality of its peasant constituency. ${ }^{57}$ Rationality and economic success were important pillars in the Party's claim for legitimacy.

The second, less explicit but equally important, dimension of the assembly was the charismatic relation to be formed between labor heroes (as representatives of the masses) and the Party leadership, in particular Mao Zedong. This was a new pillar in the creation of legitimacy. Indeed, the labor hero assembly was the place where a charismatic relation between Mao and the masses was first established, face to face and on the stage, using all the performative potential a stage naturally offers. ${ }^{58}$ This "magic of the presence" 59 was further perpetuated through newspaper articles of various types, which, taken together, reflected the Party's efforts at establishing mutuality of recognition between Mao as the paramount leader on the one hand and the labor heroes as representatives of the people on the other hand. The Party recognized labor heroes as the zhuangyuan of the new society and honored them for their individual contributions; the labor heroes, for their part, recognized Mao Zedong as their "leader" or even as the "savior" of the common people and professed ultimate loyalty to him. The various symbolic practices employed during the labor hero assembly and the sentiments they evoked-the ceremoniousness of the decoration, music, and choreography of the actors; the fine balance between distance and direct address the Party assumed vis-à-vis the labor heroes; the strong emotions displayed by the labor heroes-expressed the significance of this charismatic relation for the creation of legitimacy and also mirrored common practices in the construction of charisma. ${ }^{60}$ As we can see from the sequence of events and its coverage in JFRB, Mao's position as an exceptional leader was the result of careful orchestration and communication on the side of the Party. Configurations on the stage of the labor hero assembly were the sensual expression of new relations of power in the transition towards socialism. ${ }^{61}$

The opening ceremony was covered on the front page of JFRB of 27 November, together with the woodcut portraits of eleven labor heroes and Gao Gang's 高崗 speech at the ceremony (in which he called the labor heroes the zhuangyuan of the new society). ${ }^{62}$ The ceremony was actually dedicated to two events, the opening of the labor hero

\footnotetext{
${ }^{57}$ For rationality as a basic characteristic in the representation of labor heroes, see Spakowski, "Yan'an's labor heroines."

${ }^{58}$ For the assembly as a place where particular relations between labor heroes, Mao and the audience were established, see also Wu, "Shenfen," 152-57.

${ }^{59}$ Schneider, "Charisma," 143.

${ }^{60}$ Ebertz, "Charisma und 'das Heroische,," Schneider, "Charisma," Rauer, "Magie der Performanz," Ursprung, "Inszeniertes Charisma," and Leese, The Cult of Personality.

${ }^{61}$ For the dramaturgic and visual representation of power, see Politische Inszenierung im 20. Jahrhundert: Zur Sinnlichkeit der Macht, edited by Sabine R. Arnold, Christian Fuhrmeister, and Dietmar Schiller (Vienna: Böhlau 1998).

62“Gao Gang tongzhi zai bianqu."
} 
assembly and the production exhibition. According to the article, it took place in front of an audience of 30,000 people. ${ }^{63}$ This impressive number cannot be verified, but it contributed to the impression that the masses were attracted by the event and perceived the labor heroes as their own representatives. Indeed, the article called the labor heroes "outstanding representatives of the people of the border region" and noted that "the labor heroes ceaselessly received words of envy or praise from the masses they were passing, who found that this was their own honor." ${ }^{\text {"6 }}$ This event was as much about the elevation of labor masses as it was about the elevation of the heroes. The recognition of the masses was further emphasized by the presence of the entire political leadership of the time, including Mao Zedong and Zhu De.

The ceremony was staged in an exceptionally celebratory way. The square was decorated with red-tassled spears and flags. Large photos of eleven labor heroes, including Wu Manyou and other celebrated figures, were placed in front of the stage. Adorned with red flowers, the labor heroes, after watching the performance of a number of yangge 秋歌, ${ }^{65}$ entered the scene in a solemn way, led by posters of Mao Zedong, Zhu De, and four other leaders and accompanied by music played by a band and the applause of the audience. Five political leaders delivered speeches, starting with Lin Boqu 林伯渠, the head of the border region's government, and followed by Zhu De, He Long 賀龍, Gao Gang, and Fan Tingsheng 範亭生. Speeches by representatives of the labor heroes, the article pointed out, were scheduled for the next meeting. The ceremony was closed "under the imposing shouting of slogans." The opening ceremony thus united the political leadership and labor heroes as representatives of the people on one single stage, in a sophisticated display of equality and hierarchy.

The second highlight of the conference, and an even better opportunity for JFRB to suggest a charismatic relation between the labor heroes and Mao Zedong, was Mao's individual appearance on stage on 29 November, when he delivered his speech "Get Organized," and the banquet that followed his speech. In his speech, Mao praised the "great creative power" of the masses and dignified labor heroes as "leaders of the people." 66 The speech was printed on the front page of JFRB of 2 December, ${ }^{67}$ together with a woodcut portrait of Mao and a congratulatory message to Mao Zedong, signed by labor heroes who represented the Yanshu subregion. A report on the event appeared on 1 December and began with the words "Let's go to Yan'an and see Chairman Mao.' This long-cherished wish of more than two hundred labor heroes came true the day before yesterday." While the article indicated the solemnity also of this event, its emphasis was on the labor heroes' admiration for Mao and their promise to follow his call. Individual labor heroes were quoted: "See Chairman Mao, and your life will not have been in vain." "Look, Chairman Mao is treating us better than a father treats a son." "Chairman Mao originates from us common people." ${ }^{68}$ These expressions of closeness and devotion were continued in an article of 3 December which exclusively covered the

\footnotetext{
${ }^{63}$ For all information on the ceremony, see "Liang da shenghui zuo longzhong kaimu” 兩大盛會做隆重 開幕, Jiefang Ribao, 27 November 1943.

${ }^{64}$ In addition, a certain Lao Liu was quoted who had come from a village thirty $l i$ away and claimed that, if the way hadn't been so long, the entire village would have come ("Liang da shenghui zuo").

${ }^{65} \mathrm{~A}$ form of folk dance.

${ }^{66}$ Mao, "Zuzhi qilai."

${ }^{67}$ Mao, "Zuzhi qilai."

68“Mao Zhuxi haozhao ba quanbu laodongli zuzhi qilai” 毛主席號召把全部勞動力組織起來, Jiefang Ribao, 1 December 1943.
} 
labor heroes' reactions to meeting Mao and listening to his speech. ${ }^{69}$ This article obviously aimed at a high degree of authenticity, describing a lively scene of labor heroes and heroines in conversation with each other. Those quoted were identified by their name, place of origin and their appearance, and all quotes were rendered in colloquial language. Participants confirmed the correctness of Mao's ideas, promised to act according to his suggestions, and expressed their gratitude and "highest respect" towards the "great leader of the people." Female labor hero Guo Fengying 郭鳳英 was depicted in her conversation with textile hero Old Woman Liu. Both women had been so excited about the experience, the text reported, that they could not fall asleep the night of the invitation. Guo was overwhelmed with tears when comparing her old life with her new existence: "In the old society, we were worse off than cattle. Who cared when we were walking at night and fell into the water? Today, Chairman Mao treats us to a feast, invites us to watch a play, and even brings us back to our lodging by car. Is there a mother or father under heaven who can keep up with this"? ${ }^{70}$

For seventeen labor heroes, another direct meeting with Mao was scheduled for 9 December, after Mao's visit of the production exhibition. Each of them was introduced to Mao individually, they shook hands and the heroes talked about their experience in their respective fields of production as well as their biographies, centering on the contrast between the old and the new society and on the material improvements through fanshen and hard work. The peak was reached when labor hero (and poet) ${ }^{71}$ Sun Wanfu started up from his chair, approached Mao, embraced Mao's shoulders with his two hands and listed all the things he had gained through the revolution, finally exclaiming: "Without you, we poor fellows would creep on the ground and never be able to stand up." 72 More activities were scheduled within the twenty days of the assembly. The closing ceremony on 16 December once more united political leaders and labor heroes on one stage. The leaders delivered speeches on various aspects of the Production Movement and awarded prizes in three ranks. Again, an entire page of JFRB was dedicated to the event, including woodcut portraits of the twenty-five labor heroes of the first rank. ${ }^{73}$

Congratulatory messages in written form were yet another type of text that expressed labor heroes' gratitude and devotion to Chairman Mao. The one published on 2 December (but dated 29 December) was signed by the most prominent among the labor heroes, Wu Manyou, Zhao Zhankui, Shen Changlin 申長林, and Yang Chaoju 楊朝巨, in the name of the forty-five labor heroes who represented the Yanshu subregion. ${ }^{74}$ They addressed Mao Zedong as "dear Chairman Mao" and opened their message with a recapitulation of the history of the revolution, Mao's role therein, and their insight that Mao did everything to improve their lot. They further listed their experience

\footnotetext{
69“Laodong yingxiongmen huanxin guwu xiangying Mao Zhuxi de haozhao" 勞動英雄們歡欣鼓舞相 應毛主席的號召, Jiefang Ribao, 3 December 1943.

${ }^{70}$ Labor heroines differed from their male counterparts in that journalists and writers related them not only to general concerns of production and political legitimacy, but also to the question of women's liberation. See Spakowski, "Yan'an's Labor Heroines."

${ }^{71}$ For Sun Wanfu's role as a poet, see the next section.

72“Mao Zhuxi canguan shengchan zhanlanhui, yu laodong yingxiong qinmi jiaotan” 毛主席參觀生產 展覽會, 與勞動英雄親密交談, Jiefang Ribao, 13 December 1943. This incident and Sun's words were also part of the extended title of the article.

73"Liang da shenghui longzhong."

74"Yanshu fenqu."
} 
under the guidance of Mao and other party leaders and expressed their gratitude for everything:

For generations there was nobody who could show us a way: this way is that the poor have to turn around [fanshen], they have to till the fields, raise pigs, spin cotton, and become heroes; they have to enjoy the fruits of their work. You led us on a bright and happy way; this is the happy way for our descendants. ... We have experienced in person that you are the savior [jiu xing 救星] of the Chinese people.

The final paragraph eulogized Mao as the light which shows the way and concluded with hurrahs on Mao and the Party:

Chairman Mao, you resemble a bright light which shows us the way ahead; we will walk with you forever. We are so happy! Our descendants will be even happier. The revolution will definitely gain a great victory. We can't refrain from shouting: Long live the Chinese Communist Party! Long live Chairman Mao!

More messages with similar words followed on the following day, addressing Mao Zedong or Zhu De and signed by representatives of various subregions. ${ }^{75}$ However, these addresses were not genuine and unique expressions of workers and peasantsmost of whom were illiterate and probably not even the real authors of these texts. Gao Gang, in his speech of 5 December, called Mao the "savior of the Chinese people," "lighthouse [deng ta 燈塔] of the workers and peasants" and "banner of the hardworking masses," 76 thus revealing the Party as the original source of Mao's glorification.

Finally, a one-page "manifesto" of the labor heroes published on the front page of JFRB on 17 December elaborated on all the points mentioned so far: the labor heroes' gratitude towards the Party leaders who had improved their lives and saw them "like brothers and sisters of the same family"; and the promise to "follow them forever." In particular, they felt the obligation to follow Chairman Mao's call to "get organized" and listed nine concrete policies they intended to support, e.g., spreading labor exchange, recruiting workers among resettlers, and mobilizing women for production. ${ }^{77}$ The manifesto reads like an oath of allegiance, taken as a direct response to the symbolic recognition received by the Party. The manifesto also shows that by the time of the assembly, labor heroes were no longer mere proof of the benefits of hard work and progressive cultivation methods at the individual level but had turned into multipliers of new policies and quasi cadres in their implementation. ${ }^{78}$ This proximity to the function of cadres made them politically vulnerable-as the second labor hero assembly would prove.

\footnotetext{
${ }^{75}$ See pp. 2 and 3 of JFRB of 3 December 1943. See also a letter Wu Manyou had written to Mao where he volunteered to undertake part of the work Mao had planned as his own contribution to production in 1944. Wu is quoted: "To work on your behalf is my biggest honor, the happiest and most delightful thing in my life." See “Wu Manyou tongzhi wei Mao Zhuxi dai geng” 吳滿有同志為毛主席代耕, Jiefang Ribao, 11 February 1944.

76“Gao Gang tongzhi zai Xibei ju zhaodai laodong yingxiong dahui shang de jianghua” 高崗同志在西 北局招待勞動英雄大會上的講話, Jiefang Ribao, 11 December 1943.

77“"Shaan Gan Ning bianqu di yi jie laodong yingxiong daibiao dahui xuanyan” 陝甘寧邊區第一屆勞動 英雄代表大會宣言, Jiefang Ribao, 17 December 1943.

${ }^{78}$ See also Mai, "Wu Manyou yundong," 35, on the collectivist turn in the Wu Manyou movement.
} 
The second labor hero assembly took place between 22 December 1944 and 14 January 1945, was larger in terms of the number of hero titles to be awarded, namely to 476 persons, but received less coverage in JFRB and, most importantly, was marked by a rather negative tone. We can only speculate about the reasons for this turn. One of the reasons was certainly the aforementioned lack of consensus within the Party about the true field of heroism-production or defense. ${ }^{79}$ Another reason must have been the reconceptualization in the CCP's understanding of the function of labor heroes from representatives of the masses to quasi-cadres and a bridge between the Party leadership and the people. ${ }^{80}$ Gaining a status within the political system obviously entailed treatment similar to regular cadres, namely rectification. The slogans put up for the second assembly, the speeches by the political leaders and the quotations from labor heroes were replete with terms such as "criticism" and "self-criticism." In particular, labor heroes were warned of being “complacent” (ziman 自滿). These negative tones could already be found in the headlines of articles on the topic. ${ }^{81}$ A JFRB editorial of 28 December 1944 even turned “shortcomings" (quedian 缺點, the common wording at the time) into “doctrines" (zhuyi 主義)—a term that was reminiscent of the attacks on political aberrations during the Rectification Movement. The article decried "departmental selfishness" (benweizhuyi 本位主義)—among “the comrades of individual regions" who bragged about their individual or their own regions' successes while ignoring that of others—and the “thirst for titles” (jinbiaozhuyi 錦標主義, literally: "titleism") of "individual labor heroes" who "were merely eager to gain a reputation, an award, and publicity." 82 The forms of mutual appreciation which had marked the first labor hero assembly were missing in the second one. Obviously, the Party's approach to the labor heroes had changed from cherishing them as representatives of the masses to regulating them as quasi-cadres of a political campaign.

\section{The Formation of a Socialist Subjectivity in the Encounter between Labor Heroes and Writers}

The enhancement of the status of labor heroes, as representatives of the masses, was accompanied by the degradation of intellectuals. Intellectuals were a problematic group in various respects: in their traditional role as providers of legitimacy and as potential critics of the new order, if not outright contenders for power; ${ }^{83}$ in their dubious class status, tending towards "petty bourgeoisie"; 84 and in their urban origin and

\footnotetext{
${ }^{79}$ See Part 1 of this article.

${ }^{80}$ See the editorial in JFRB of 5 September 1944 titled "Caiyong xin de zuzhi xingshi yu gongzuo fangshi” 採用新的組織形式與工作方式, Jiefang Ribao, 5 September 1944. See also Mao's speech at the second assembly where, right at the beginning, he picked up the three functions mentioned in the editorial, namely that of “pioneers” (daitou 帶頭) in work, “mainstay” (gugan 骨干) as a pre-stage of a formal cadre position, and "bridge" (qiaoliang 橋梁) between the political leadership and the masses (Mao Zedong, "Liang san nian nei wanquan xuexi hui jingji gongzuo” 兩三年內完全學習會經濟工作, Jiefang Ribao, 12 January 1945).

${ }^{81}$ For all these characteristics, see, for instance, the report on the opening ceremony "Bianqu qunying dahui kaimu: Lin zhuxi zhi kaimu ci haozhao yizhi ziman, li qiu jinbu” 邊區群英大會開幕。林主席致 開幕詞號召抑制自滿, 力求進步, Jiefang Ribao, 23 December 1944.

82“Guanche shi shi qiu shi de jingshen” 貫徹實事求是的精神, Jiefang Ribao, 28 December 1944.

${ }^{83}$ Merle Goldman, Literary Dissent in Communist China (Cambridge: Harvard University Press, 1967), 18-50; Dai and Apter, eds, Wang Shiwei and "Wild Lilies"; and Gao, How the Red Sun Rose.

${ }^{84} \mathrm{Wu}$, "Shilun 40 niandai Yan'an wentan”; U, Creating the Intellectual.
} 
alienation from rural life and from the peasants. ${ }^{85}$ At the same time, they were indispensable for the very construction of a new symbolic order. Writers and artists, in particular, in their function as "cultural workers," were needed to illustrate new social relations in literary and artistic products that fulfilled the cultural policies promulgated at the authoritative "Yan'an Forum on Literature and Art" (henceforth: "Yan'an Forum") in May 1942.

Studies on the Rectification Movement and the Yan'an Forum have demonstrated how intellectuals, writers, and artists were subordinated to the Party line and how individual writers opposed or confirmed the new policies. ${ }^{86}$ While existing work highlights the relation between the Party and intellectuals, I want to move the perception of social life in Yan'an from a dichotomic to a configurational view. My focus here is on the way the Party conceptualized new cultural practices in terms of the relation between writers and labor heroes and how it made labor heroes the preferred objects and also subjects of art and literature. Relationality and intersubjectivity mattered for the very process of constructing a socialist self: ${ }^{87}$ It was in the face of labor heroes that intellectuals were expected to "reform themselves" and develop a new subjectivity. At the same time, the very fact of meeting the labor heroes as well as performative acts of addressing them made intellectuals midwifes in the emergence of a new peasant subjectivity. While the Party was definitely the source of establishing new cultural practices, we should be cautious about interpreting the encounters described below as mere acts of submission to the will of the Party. Rather, they form yet another chapter in a long tradition of intellectuals' self-doubt about their place in socialist society and genuine feelings of alienation from the "masses." 88

The principles established for culture or, literally, wenyi 文藝 (art and literature) in Mao's talks at the Yan'an Forum are well known and are summarized here only with regard to those aspects relevant for our topic. ${ }^{89}$ Mao held that culture was shaped by class, and cultural workers had to take up the correct class standpoint, namely the standpoint of the proletariat (i.e. workers, peasants, and soldiers) and the Party, and they had to serve the revolution. ${ }^{90}$ Mao left no doubt that the Party was determined to enforce these principles among intellectuals and stated the need of a "conscientious and severe rectification movement" among cultural workers. ${ }^{91}$ At the same time, he acknowledged the reciprocity between culture and politics: "Culture is subordinated to politics, but, conversely, it also has a tremendous influence on politics."

\footnotetext{
${ }^{85}$ See below.

${ }^{86}$ Dai and Apter, eds, Wang Shiwei and "Wild Lilies"; Apter and Saich, Revolutionary Discourse; Gao, How the Red Sun Rose; U, Creating the Intellectual.

${ }^{87}$ For relationality and intersubjectivity in the formation of the subject, see Ricken, "Anerkennung als Adressierung" and Ricken, "Zur Logik der Subjektivierung."

${ }^{88}$ Wang-chi Wong, Politics and Literature in Shanghai: The Chinese League of Left-Wing Writers, 19301936 (Manchester: Manchester University Press, 1991); Hung-yok Ip, Intellectuals in Revolutionary China, 1921-1949: Leaders, Heroes and Sophisticates. (London: RoutledgeCurzon, 2005); Nicola Spakowski, "Dreaming a Future for China: Visions of Socialism among Chinese Intellectuals in the Early 1930s," Modern China 45:1 (2019), 91-122.

${ }^{89}$ Mao Zedong, “Zai Yan'an wenyi zuotanhui shang de jianghua” 在延安文㙯座談會上的講話, in Yan'an wenyi congshu 延安文藝叢書, edited by Yan'an wenyi congshu bianweihui, vol. 1: Wenyi lilun juan 文藝理論卷 (Changsha: Hunan wenyi, 1987), 1-29.

${ }^{90}$ Mao, “Zai Yan'an wenyi zuotanhui shang," 2-5.

${ }^{91}$ Mao, "Zai Yan'an wenyi zuotanhui shang," 25.

${ }^{92}$ Mao, “Zai Yan'an wenyi zuotanhui shang," 17.
} 
indispensable for the revolution just like a gear wheel or a screw are indispensable for a machine. ${ }^{93}$ The relation between cultural workers and the masses is mutual, too: "If intellectuals want to unite with the masses and serve the masses, this necessitates a process of mutual understanding." ${ }^{94}$ However, some of the cultural workers, according to Mao, assumed a petty bourgeois standpoint: "With regard to the masses of workers, peasants, and soldiers, they lack closeness, understanding, research, and [a relation of] intimate friendship; they are not good at portraying them; when they portray them, their clothes are those of the working people, but their face is that of petty bourgeois intellectuals." 95 Obviously, emotional, cognitive, and artistic principles formed an integrated whole in the relation between the two groups. For our purpose, the question of how to portray the masses-and social reality in general-is of particular importance. In Mao's view, products of art and literature, in order to awaken and motivate the masses to take up struggle, have to reflect social reality "in a higher, sharper, more concentrated, more typical, more idealistic, and thus in a more general way than average real life." 96 Cultural workers were expected to “praise” (gesong 歌颂) the "bright” (guang-ming 光 明) sides of the border region rather than “exposing” (baolu 暴露) the “dark" (heian 黑暗) ones ${ }^{97}$-a statement directed against writers such as Wang Shiwei 王實味 or Ding Ling 丁玲, whose essays had exposed the flaws of Yan'an society. This distinction was more than just a matter of criticism versus confirmation of communist policies, though. It was a question of identifying the "bright" as the "new" (new people, new masses, a new world) and the marker of a new age that was already present in the border regions. The principle of "praising" the "bright" sides introduced a strong utopian moment into cultural production which also affected the perception of labor heroes. ${ }^{98}$

Mao's talks at the Yan'an Forum initiated a fundamental turn in writers' theoretical reflections on art and literature and their self-positioning vis-à-vis the masses. Famous left-wing writers such as Ding Ling, Liu Baiyu 劉白羽, and Ai Qing 艾青, all known for their liberal stance before the Forum, confirmed the Maoist principles and also followed more practical instructions emanating from the Forum. ${ }^{99}$ With the launch of the Wu Manyou campaign in January 1943 and systematic propaganda for "culture going to the countryside" (wenhua xiaxiang 文化下鄉) since around Chinese New Year of $1943,{ }^{100}$ labor heroes became a core subject in texts based on the new cultural principles. Writers were encouraged to go to the villages and live and work with the labor heroes in order to represent their lives and outlooks in a realistic way. And those whom the Party deemed successful, such as Ai Qing, Gu Yuan 古元, and Ke Lan 柯藍, were for their part awarded the title labor hero. ${ }^{101}$

\footnotetext{
${ }^{93}$ Mao, “Zai Yan'an wenyi zuotanhui shang," 17-18.

${ }^{94}$ Mao, “Zai Yan'an wenyi zuotanhui shang," 27.

${ }^{95}$ Mao, "Zai Yan'an wenyi zuotanhui shang," 9.

${ }^{96}$ Mao, "Zai Yan'an wenyi zuotanhui shang," 13.

${ }^{97}$ Mao, "Zai Yan'an wenyi zuotanhui shang," 2.

${ }^{98}$ For the repercussions of "praising" the "bright" sides in genre, and a more fundamental discussion of the utopian dimension in the portrayal of labor heroes, see Spakowski, "Yan'an's Labor Heroines."

${ }^{99} \mathrm{~A}$ number of writers explained their new attitude in a collection of articles which appeared on 15 June 1942 in Volume 5 of the literary journal Guyu 谷雨; see Yan'an wenyi congshu and Wu, “Shilun 40 niandai Yan'an wentan."

${ }^{100} \mathrm{Li}$, "Yan'an wenyi zuotanhui," 17 . For the development of the xiaxiang movement, see Zhang, "Kang Ri genjudi."

${ }^{101} \mathrm{Ai}$ Qing, Gu Yuan and Ke Lan appear in the list of labor heroes honored at the second labor hero assembly. See “Qunying guangrong shoujiang” 群英光榮受獎, Jiefang Ribao, 14 January 1945.
} 
Early evidence of programmatic efforts at bringing writers/artists and labor heroes together can be found on page 4 of JFRB, 10 February 1943. The page contained the report of a meeting between more than two hundred cultural workers with the three labor heroes Wu Manyou, Zhao Zhankui, and Huang Lide 黃立德 on 6 February; ${ }^{102}$ a woodcut New Year print of Wu Manyou by Gu Yuan; an article by JFRB chief editor Lu Dingyi 陸定一 on wenhua xiaxiang, which was inspired by Gu's picture; and reportage by Ke Lan on "Wu Manyou and the People of His Village," which was the result of a direct meeting between $\mathrm{Wu}$ and the author. In his report on the meeting of 6 February, Mo Ai 莫艾 made labor heroes the "masters of New China." ${ }^{03}$ On 17 February, JFRB published the poem "Welcoming the Three Labor Heroes" (Huanying san wei ladong yingxiong 歡迎三位勞動英雄) by Ai Qing, which had been read to the three labor heroes at the occasion of the meeting. ${ }^{104}$ Another product of this meeting was $\mathrm{Ai}$ Qing's poem "Wu Manyou," published on 9 March. Indeed, Wu Manyou's prominence made him the subject of quite a number of cultural works. ${ }^{105}$ Another conference on the Party's cultural workers convened by the CCP on 10 March 1943 confirmed the Party's principles and stressed the need for writers to live and work with the masses. A long report on the conference quoted from Mao's talks at the Forum and paraphrased speeches of political leaders, Kai Feng 凱豐, deputy chief of the CCP's propaganda department, among them. The ultimate goal, the report claimed, was to "truly transform the thoughts and feelings of writers, truly gain rich knowledge of the life of the masses, and truly produce works that correctly reflect this era." ${ }^{106}$ This conference and the meeting in February formed the origin of many wenhua xiaxiang activities. Writers and artists, as individuals or as troupes, spent time in the villages to live and work with the peasants and perform for them. Writers wrote on individual labor heroes, based on direct meetings with them. Moreover, the movement of going to the villages was further theorized. ${ }^{107}$ Using assemblies as an opportunity for intellectuals to get into direct contact with peasants was encouraged, too. ${ }^{108}$

The relation between writers and labor heroes was further mentioned in a few theoretical texts. ${ }^{109}$ More important was the influence of concrete products of art and literature, through, for instance Ai Qing's poems "Welcoming the Three Labor Heroes" and "Wu Manyou." Ai Qing belonged to those writers who confirmed Mao's cultural

\footnotetext{
${ }^{102} \mathrm{Mo}$ Ai 莫艾, “Bizha, chutou he chuizi一texie wenhua jie huanying san yingxiong” 筆札，鋤頭和錘 子一特寫文化界歡迎三英雄, Jiefang Ribao, 10 February 1943. See also Li, “Yan’an wenyi zuotanhui,” $17-18$.

${ }^{103} \mathrm{Mo}$, "Bizha."

${ }^{104}$ See below.

${ }^{105} \mathrm{Lu}$ Yang 路楊, “Zuo wei shengchan de wenyi yu nongmin zhuti de chuangsheng-Yi Ai Qing changshi “Wu Manyou' wei zhongxin” 作為生產的文藝與農民主題的創生一以艾青長詩《吳滿有》為中心, Wenxue pinglun 2018.6, 110-18, here, 112.

106“Zhongyang wenwei zhaokai dang de wenyi gongzuozhe huiyi” 中央文委召開黨的文㙯工作者會議, Jiefang Ribao, 13 March 1943. The Mao quotes are important because the full text of his talks at the Forum were only published on 19 October 1943.

${ }^{107}$ Zhang, "Kang Ri genjudi" and Chen and Song, "Wenyi xiaxiang."

${ }^{108}$ Xiao San 蕭三, “Di yi bu一Cong canjia bianqu canyihui ji laomo dahui gui lai” 第一步一從參加邊 區參議會及勞模大會歸來, Jiefang Ribao, 20 February 1945. See also Mao’s positive reaction to Xiao’s text in a letter where he advised the author to pursue this option in a systematic manner: Mao Zedong 毛澤東, “Zhi Xiao San” 至蕭三, 22 February 1945, reproduced in Yan'an wenyi congshu, 79.

${ }^{109}$ Kai Feng 凱豐, “Guanyu wenyi gongzuozhe xiaxiang de wenti-Zai dang de wenyi gongzuozhe huiyi shang de jianghua, yijiusisan nian san yue shi ri” 关於文藝工作者下鄉的問題一在黨的文藝工作者會 議上的講話, 一九四三年三月十日, Jiefang Ribao, 28 March 1943; Xiao San, “Di yi bu.”
} 
policy at an early stage. ${ }^{110}$ Himself a critical writer before the Forum, he was even among those who publicly attacked Wang Shiwei, ${ }^{111}$ thus leaving no doubt that he had fully embraced Mao's directions on art and literature. This fundamental turn was also reflected in the poems written after the Forum. At the same time, he displayed his self-transformation vis-à-vis the labor heroes and created new identities for writers and labor heroes in a relational way in his work. "Welcoming the Three Labor Heroes" used the Production Movement and related slogans and political leaders as a framework to pit "cultural workers" (wenhua ren 文化人) against labor heroes. Ai used one of four stanzas to describe his own, fruitless efforts at agricultural cultivation, culminating in the self-incriminating statement that "We 'cultural workers' are indeed useless." 112 In the final stanza, he proclaimed that the writers had invited the three labor heroes in order to learn from them.

Ai Qing's second poem, "Wu Manyou," together with a small woodcut portrait of $\mathrm{Wu}$, covered an entire page of JFRB. Again, the meeting between writers and the three labor heroes in February 1943 formed the background of the plot. Ai portrayed $\mathrm{Wu}$ as a “new type of peasant” (xin de nongmin dianxing 新的農民典型), using 120 stanzas grouped into nine parts, each of which covered a particular period or aspect of Wu's life. The poem was accompanied by a "supplement" in prose where Ai described his visit to Wu's village on 15-16 February 1943 and the face-to-face encounter between the two, arranged in order to get Wu's authorization for the poem. It is the supplement where Ai defined his own role vis-à-vis $\mathrm{Wu}$, the labor hero.

There is no space here to cover the poem in detail. For our purpose, two aspects are important, both of which contribute to the specific relation between intellectuals, labor heroes, and Mao Zedong: First, $\mathrm{Ai}$, the poet, read the entire poem to $\mathrm{Wu}$, line by line, in order to give him the opportunity to confirm or reject what he had written-a common practice in the relation between writers and labor heroes. ${ }^{113}$ In the supplement, Ai provided ten examples of statements Wu confirmed ("Yes, this is what I said.") or rejected and had Ai change the original text. Ai thus made $\mathrm{Wu}$ a co-writer, the object and subject of his own life story, and the ultimate authority over the poem and his own identity. This is particularly obvious in one longer example which demonstrates that Wu had already internalized the new identity of labor hero offered to him by the Party. Wu, according to Ai, was particularly unhappy with the phrase "people call you 'one successful in his old age' (lao lai hong 老來紅)"-Ai was forced to delete it-and contrasted it with the title "labor hero" which pleased him. While being called "labor hero," Wu explained, was an honor and the result of his own hard work, lao lai hong implied the notion of “parvenu" (bao $f a h u$ 暴發戶) and was a matter of fate. Furthermore, through constantly addressing $\mathrm{Wu}$ in the second form, Ai recognized Wu. And through many quotes, introduced with the words "you said," he gave him a voice. ${ }^{114}$ Literary

\footnotetext{
${ }^{110}$ His point of view was published in JFRB of 15 May 1942, when the Forum was not yet over, see Ai Qing 艾青, “Wo duiyu muqian wenyi shang jige wenti de yijian” 我對於目前文藝上幾個問題的意見, Jiefang Ribao, 15 May 1942. For Ai’s political turn around the Forum, see also Shang Changbao 商昌宝, “'Jianghua' de jieshou yu 'baolupai’ de zhuanxiang-Yi Liu Baiyu, Ai Qing wei kaocha zhongxin” 《講 話》的接受與”暴露派”的轉向——劉白羽、艾青為例, Xiangtan daxue xuebao 2015.5, 96-100.

${ }^{111}$ See his one-page article “Reality Does Not Allow Distortions” (Ai Qing 艾青, “Xianshi bu rongxu waiqu” 現實不容許歪曲, Jiefang Ribao, 24 June 1942.

${ }^{112} \mathrm{Ai}$ Qing 艾青, “Huanying san wei laodong yingxiong” 歡迎三位勞動英雄, Jiefang Ribao, 17 February 1943.

${ }^{113}$ This practice is mentioned in Xiao San, “Di yi bu." See also Wang Lin 王琳, “Huiyi Sun Wanfu” 回憶 孫萬福, Jiefang Ribao, 18 August 1944.

${ }^{114}$ See also Lu, “Zuo wei shengchan de wenyi," 116.
} 
scholar Lu Yang, who discussed the poem as an example of innovation in form, claims that Ai's Wu Manyou "is the image of a peasant who changed his fate, has a discourse, a voice, an opinion, and self-awareness." ${ }^{115}$ Indeed, contemporaries saw the poem as an example for the new image of the masses in art and literature. ${ }^{116}$

Second, and differing from "Welcoming the Three Labor Heroes," in this poem the writer has a legitimate place, too. Through the dialogic form of the poem-Ai, the writer, is the "I" implied in the "you" of Wu Manyou-and the free and easy conversation between the two described in the supplement, Ai appears as a legitimate member of the new society, and he is also the authority on the wider picture. While $\mathrm{Wu}$, the peasant, simply enjoys the festivities of the New Year, Ai teaches him why this year's festivities can be so merry: "Let me tell you point by point." Ai refers to the unequal treaties and the prospect that the inequalities would be revoked in the course of the current war; the advance of the Soviet Army in the war with Germany; the Production Movement as a support for the revolution; and the close relation between the army and the people, fighting at the front and producing in the rear. Finally, Ai gives Wu a voice also in the charismatic relation between the labor heroes and Mao Zedong: "When you, Wu Manyou, are asked 'who gave you a happy life,' you say 'Chairman Mao!' You say that without him you would not be able to live. You say, wherever he goes you will follow him." Indeed, through the tongue of the eulogized Wu Manyou, $\mathrm{Ai}$ contributes to the leadership cult. Whatever peasants such as $\mathrm{Wu}$ really thought about Mao, it was only through intellectuals such as Ai that the glorification of Mao could appear as a genuine peasant concern. Even though the aesthetic value of this poem is debatable, and even though the role it played in Ai's political rehabilitation is obvious, it is more than just a propaganda piece. ${ }^{117}$ By addressing Wu Manyou in a poem, Ai recognized a peasant-and in the image of the peasant also his own, reformed self.

A second example of relationality appeared on page 4 of JFRB of 26 December 1943, only ten days after the first labor hero assembly was concluded. In this case, relationality is achieved not only through the contents of the three articles that filled the page, but also through the page's layout which nested them into each other, thus making them an integrated whole. The three articles were "A Labor Poet Who Cannot Read and WriteSun Wanfu” (Yi wei bu shi zi de ladong shiren-Sun Wanfu 一位不識字的勞動詩人 ——孫萬福) by cultural authority Zhou Yang 周揚, accompanied by a small woodcut portrait of Sun; writer Liu Baiyu's “Notes Upon Reading Comrade Mao Zedong's 'Talks at the Yan'an Forum on Art and Literature" (Du Mao Zedong tongzhi "Zai Yan'an

\footnotetext{
${ }^{115} \mathrm{Lu}$, "Zuo wei shengchan de wenyi," 115.

${ }^{116}$ Liu Baiyu 劉白羽, “Xin de yishu, xin de qunzhong” 新的㙯術, 新的群眾, Qunzhong 9.18 (1944), reproduced in Zhongguo xiandia wenxue shi cankao ziliao, Wenxue yundong shiliao xuan 中國現代文 學史參考資料，文學運動史料選, edited by Beijing daxue, Beijing shifan daxue, Beijing shifan xueyuan, Zhongwenxi Zhongguo xiandai wenxue jiaoyan, 5 (Shanghai: Shanghai jiaoyu, 1979), 81-94, here 90-91.

${ }^{117} \mathrm{Lu}$, "Zuo wei shengchan de wenyi," 117 , highlights the creative side of the poem but does not hide his reservations about its aesthetic value. Zhou Weidong treats the poem as an example of the limits imposed on writers through the new cultural policies. He stresses the closeness of the poem to the newspaper articles on Wu Manyou which he interprets as a loss of intellectuals' "right to take initiative"; see Zhou Weidong 周維東, “Bei 'zhen ren zhen shi' gaixie de lishi-Lun jiefang qu wenyi yundong zhong de 'zhen ren zhen shi” chuangzuo” 被“真人真事”改寫的歷史——論解放區文藝運動中的“真人真事”創作, Zhongshan daxue xuebao 2014.2, 65-73, here, 69. Yuan, "Yan'an shiqi wenren xintai," 64, treats the poem as an example of intellectuals' self-denial.
} 
wenyi zuotanhui shang de jianghua” biji 讀毛澤東同志《在延安文藝座談會上的講 話》筆記 $)^{118}$; and a rather short call for articles by the editors who encouraged writers to send in their new pieces written in the spirit of the Forum. Basically, one can read the page as a relational reassessment of status between Sun Wanfu and Liu Baiyu, the two representing the masses and intellectuals respectively, as well as Mao Zedong vis-à-vis intellectuals and the masses.

Labor hero Sun Wanfu ${ }^{119}$ had come to prominence through the scene described above, when the group of seventeen labor heroes had met with Mao Zedong in person and Sun had praised him as the source of all he had and was. ${ }^{120}$ In his article on Sun as a labor poet, Zhou Yang referred to this incident as "a moving scene," "a very beautiful poem," and "a correct painting of the relation between the people and its own leader," thus aestheticizing the scene and displaying his own literary sophistication. ${ }^{121}$ Furthermore, Zhou described how he had come into contact with Sun, had written down the poems Sun had recited to him, quoted five of these poems, explained the poet's significance, and commented on the poems by highlighting particular lines which he praised for their literary quality, in particular the figurative language used, and the "correctness" of their contents. The second of the poems is particularly noteworthy because it fitted the glorification that had already marked the labor hero assembly and a general surge in poems and songs which glorified Mao. ${ }^{122}$ The first line of Sun's poem read "Our Chairman Mao resembles a sun." This sun, which he further compared to a flower rising above the sea in the east and a piece of gold coming from the sky, shines on the border region and its people. For Zhou, the five lines of the poem reflected "the kind love of the people towards their own leader." He also defended the poem against the "pedantic standpoint of rhetoric" which might criticize the "confusion" in these metaphors (comparing a flower to the sea and a piece of gold to the sky), thus indicating that the literary value of the poem was debatable.

A labor hero turned poet was of course an excellent reflection of cultural policies which required culture to express the needs of the masses. Furthermore, a poet from the masses who was also an illiterate constituted a perfect counterpart to intellectuals who had received an education but lacked a mass standpoint. In his article, Zhou on the one hand made Sun a typical labor hero: "Not differing from other labor heroes, his words are simple and clear; each sentence is filled with joy about work, care for

\footnotetext{
${ }^{118}$ Liu Baiyu 劉白羽, “Du Mao Zedong tongzhi 'Zai Yan'an wenyi zuotanhui shang de jianghua' biji” 讀毛澤東同志《在延安文藝座談會上的講話》筆記, Jiefang Ribao, 26 December 1943.

${ }^{119}$ Biographical information on Sun Wanfu (1883-1944) is scarce. He was born in Quzi, eastern Gansu province, to a poor family which could not afford to give him an education, which is why Sun never learned to read and write. With the arrival of the Red Army in 1936, the Sun family received land, and the family's fate improved. In 1940, Sun joined the CCP; in November 1943 he was awarded the title labor hero and participated in the first labor hero assembly. In 1944 Sun drowned when crossing the Huai river. Sun is particularly known for the moving scene at the labor hero assembly and for his poems, in particular those praising Mao Zedong. See "Liushi sui laodong yingxiong Sun Wanfu" 六十歲勞動英雄孫萬福, Jiefang Ribao, 16 January 1944 and Zhao Fafa 趙法發, "Nongmin, laodong yingxiong yu shiren: Sun Wanfu de geti shenghuo shi” 農民、勞動英雄與詩人: 孫萬福的個體生活史, Zhongguo Yan'an ganbu xueyuan xuebao 2016.7, 95-100.

${ }^{120}$ See above and "Mao Zhuxi canguan."

${ }^{121}$ Zhou Yang 周揚, “Yi wei bu shi zi de ladong shiren一Sun Wanfu” 一位不識字的勞動詩人一孫萬 福, Jiefang Ribao, 26 December 1943.

${ }^{122}$ Cai Jie 蔡潔, “Yan'an shiqi zhengzhi wenhua de xiezhao-yi 'Mao Zedong songge’ wei li de fenxi” 延安時期政治文化的寫照——“毛澤東頌歌“為例的分析, Zhongbei daxue xuebao, 2016.4, 32-37.
} 
the collective, belief in and loyalty to the revolution and his own leader." On the other hand, he stressed Sun's extraordinary qualities as a poet, thus making sure that readers would appreciate them as true literary work.

Liu Baiyu's "Notes," by contrast, provided the self-degradation of an intellectual who, in the light of Mao's words, realized his "petty bourgeois" (xiao zichan jieji 小資產階級) perspective and the lack of a true mass standpoint. Liu introduced his thoughts with the sentence "Supporting Chairman Mao's orientation towards the masses, in my case first of all [means that] I have to undertake self-criticism." Liu's text was the first response of a writer to Mao's "Talks" after their publication in JFRB of 19 October 1943, and it was typical of those to follow. ${ }^{123}$ It was replete with Mao quotations, class language, and the specific vocabulary of the Rectification Movement. Liu confessed that, even though he had been on the side of the revolution and had already discovered peasants as a topic for his work, he had not really seen the masses. He scrutinized his earlier work and listed his mistakes in the conceptualization of key actors. In this and in later texts, ${ }^{124}$ he revealed the struggle of an author who felt alienated from the masses as the true subjects of history, the substance of community, and the object of his work. In the "Notes" this alienation is particularly obvious where Liu (employing a Mao quotation) referred to a scene in 1939 when he attended a peasant assembly:

I couldn't come close to them; I didn't know what to talk about with them; standing in front of them, I felt lonely; I felt that I was another kind of person, a stranger. Even though I participated in this peasant assembly from start to finish, I didn't understand them and they didn't understand me. Therefore, one can say that the figures in my work were intellectuals in peasants' clothes; a sort of fake peasants, people who weren't related by blood with the soil, work, revolution, and war. This led to a long-standing dejection concerning my works. ${ }^{125}$

In his article "New art, new masses" ${ }^{126}$ published in 1944, Liu Baiyu turned from selfcriticism of past mistakes to the possibilities of the future. He talked about the "new figures" in a "new reality" which he found in concrete examples of art and literature that had been produced in the spirit of the "Forum"-Ai Qing's poem "Wu Manyou" among them. ${ }^{127}$ Liu wanted writers to "tell us what our life will look like in the future" and saw the heroes of an age as the key to understanding the direction the future will take. ${ }^{128}$ Finally, in his report “Life in Yan'an” (Yan'an shenghuo 延安生活), published in 1946, Liu Baiyu presented a Yan'an with markedly romantic and utopian features, using a narrative that combined a view on the material transformation of the border region with social scenes of happiness and insights into the transformation of his own self. Individual scenes of life in Yan'an, some of them featuring labor heroes, illustrated a vision of society where work-balanced with leisure-was the source of all progress and happiness. It was through the writer's immersion in this collective life of happiness that he managed to overcome his own feelings of alienation and isolation and find a place in socialist society. ${ }^{129}$

\footnotetext{
${ }^{123}$ Shang, "Jianghua' de jieshou," 97.

${ }^{124}$ Liu Baiyu, Yan'an shenghuo 延安生活 (Shanghai: Xianshi, 1946).

${ }^{125}$ Liu Baiyu "Du Mao Zedong."

${ }^{126}$ Liu Baiyu, "Xin de yishu."

${ }^{127}$ Liu Baiyu, "Xin de yishu," 90-91.

${ }^{128}$ Liu Baiyu, "Xin de yishu," 93-94.

${ }^{129}$ Liu, Yan'an shenghuo. For his individual transformation, see ibid. 23.
} 


\section{Conclusion}

Labor heroes were central in the CCP's restructuring of social relations in the Yan'an period. They could assume this role based on the new concept of work as the fundament of society, the core source of recognition and the mechanism that shapes social relations. As representatives of the "masses," their biographies of improved living conditions through fanshen and work, their allegiance to the Party and their veneration for Mao Zedong were core elements in legitimizing CCP rule and constructing a personality cult. In the field of art and literature, they figured not only as the preferred subject of works inspired by the new concept of art but became actively involved in the artistic process, as "labor poet" (Sun Wanfu), as the ultimate authority over texts featuring their own lives, or as a medium in intellectual writers' self-reform (Wu Manyou). Claims of egalitarianism notwithstanding, the new symbolic order of Yan'an was hierarchical, and processes of heroization were instrumental in creating these new hierarchies. These processes were controlled by the Party and supported by writers who had internalized the Party's new instructions on art. Considering the negative connotation of heroism in a communist context, heroic distinction remained ambiguous, though. Objects of explicit heroization were the labor heroes, but, as the alternative term "labor model" indicates, it was their exemplarity rather than their exceptionality that mattered. Labor heroes, first and foremost, were models to be emulated, and they existed in the thousands. For the masses, they were models of a new socialist subjectivity; for intellectuals, they were intermediaries in adapting to the norms of socialist society as a society of producers. Differing from the multitude of "models," true heroic status was reserved for Mao Zedong alone, as ultimate authority and as the personification of the new order. Exceptionality and extraordinariness made him a charismatic leader who was not to be emulated but venerated. Even though the term "hero" was not applied to Mao, and even though labor heroes remained the actual subject in respective texts, veneration of Mao was implied, through the praise of the labor heroes and through intellectuals who gave them a voice in the first place.

The processes described in this article proved highly relational. Labor heroes' profiles were shaped by their relation to the Party, to Mao Zedong in person, to intellectuals and to their fellow members of the "masses." Even those absent from our Chinese-language texts, such as Chiang Kai-shek, played into the labor hero movement. My emphasis on configurations and mutuality in relations of power-rather than dichotomic oppositions or absolute concepts of autonomy and oppression-does not deny the repressive sides of the Rectification Movement and the instrumentalist sides of the Production Movement. My point is that we should think about these movements together and understand the social transformation instigated through them in an inclusive way, taking account of all actors involved-political leaders, intellectuals/writers, and peasants-and recognizing the reciprocity in processes of recognition.

Cite this article: Spakowski N (2021). Moving Labor Heroes Center Stage: (Labor) Heroism and the Reconfiguration of Social Relations in the Yan'an Period. Journal of Chinese History 5, 83-106. https:// doi.org/10.1017/jch.2020.4 